\title{
PERANAN KELOMPOK KAYOMAN PEDAWA DALAM MEREVITALISASI POTENSI WISATA BERBASIS KEARIFAN LOKAL DI DESA PEDAWA, KECAMATAN BANJAR, KABUPATEN BULELENG
}

\section{THE ROLE OF KAYOMAN PEDAWA GROUP IN THE REVITALIZATION OF TOURISM POTENTIAL BASED ON LOCAL WISDOM IN PEDAWA VILLAGE, KECAMATAN BANJAR, BULELENG DISTRICT}

\author{
Putu Sabda Jayendra, I Wayan Eka Sudarmawan dan Firlie Lanovia Amir \\ Sekolah Tinggi Pariwisata Bali Internasional \\ sabda@stpbi.ac.id
}

\begin{abstract}
ABSTRAK
Kayoman Pedawa Group, directly initiated by the community of Pedawa Village aims to reconstruct and revitalize the existence of tourism potential in the form of natural, social, customs and local wisdom. The establishment of this group originated from the concerns of the community and the young figures Pedawa village will be the phenomenon of the growing nature and local wisdom with the rapid modernization. Therefore, the interest is examined from the phenomenon is and the role of the group Kayoman Pedawa in revitalizing the potential tourism-based local wisdom of Pedawa village. The theory used as a problem surgeon is the social action theory and structural functionalism theory. This research is a type of qualitative descriptive research. The results of the research is a revitalizing cultural potential based on local wisdom by Kayoman Pedawa Group of some of them are; 1) rehabilitation of forests and agricultural cultures, 2) revitalization of ancient relics into tourism destinations of village history, 3) The reconstruction of local wisdom-based attractions, such as traditional houses, gangsing games, traditional gamelan reconstruction of Pedawa, revitalizing the manufacture and product of palm sugar Pedawa, 4) provide a mentoring of foreign students who study ethnography, and 5) socialization and publication of local wisdom of Pedawa village to the outside community, such as the interactive dialogue of Thunder Singaraja Radio broadcast, Through the making of documentary films in collaboration with Minikino Bali.
\end{abstract}

Keywords: Kayoman Pedawa Group, revitalization, local wisdom

\begin{abstract}
ABSTRAK
Grup Kayoman Pedawa, yang diprakarsai langsung oleh masyarakat Desa Pedawa bertujuan merekonstruksi dan merevitalisasi keberadaan potensi wisata dalam bentuk kealamian, sosial, adat dan kearifan lokal. Pembentukan kelompok yang berawal dari keprihatinan masyarakat dan tokoh-tokoh muda desa Pedawa ini akan menjadi fenomena alam yang tumbuh dan kearifan lokal dengan modernisasi yang cepat. Karena itu, minat dikaji dari fenomena tersebut adalah peran kelompok Kayoman Pedawa dalam merevitalisasi potensi kearifan lokal berbasis wisata desa Pedawa. Teori yang digunakan adalah teori aksi sosial dan teori fungsionalisme struktural. Penelitian ini merupakan jenis penelitian deskriptif kualitatif. Hasil penelitian adalah revitalisasi potensi budaya
\end{abstract}


berdasarkan kearifan lokal oleh Grup Kayoman Pedawa di antaranya; 1) rehabilitasi hutan dan budaya pertanian, 2) revitalisasi peninggalan kuno menjadi tujuan wisata sejarah desa, 3) Rekonstruksi atraksi berbasis kearifan lokal, seperti rumah tradisional, permainan gangsing, rekonstruksi gamelan tradisional Pedawa, revitalisasi pembuatan dan produk gula aren Pedawa, 4) memberikan pendampingan mahasiswa asing yang belajar etnografi, dan 5) sosialisasi dan publikasi kearifan lokal desa Pedawa kepada masyarakat luar, seperti dialog interaktif siaran Radio Thunder Singaraja, Melalui pembuatan film dokumenter bekerja sama dengan Minikino Bali.

Kata kunci: Grup Kayoman Pedawa, revitalisasi, kearifan lokal

\section{PENDAHULUAN}

Eksistensi pariwisata sangat bergantung pada potensi alam dan budaya. Menurut Purwanto dkk (2014:1), daya tarik utama pariwisata adalah ketersediaan obyek dan daya tarik wisata alam (ODTWA) yang bersumber dari keindahan dan keunikan obyek sumber daya alam dan sosial budaya masyarakat setempat, termasuk pula flora, fauna dan lanskap serta juga nilai tambah dari atraksi budaya yang ada. Dengan demikian, maka akan menggugah dan menarik minat wisatawa untuk datang dan melihat keunikan potensi alam dan budaya tersebut, terlebih jika dikelola dengan baik.

Sehubungan dengan hal tersebut, Susyanti dan Latianingsih (2014) menyatakan bahwa dinamika wisatawan saat ini banyak beralih kepada produk wisata yang lebih menghargai lingkungan, alam, budaya dan atraksi secara spesial. Kepuasan wisatawan tidak lagi bersandar pada keindahan alam dan kelengkapan fasilitas wisata melainkan juga pada keleluasaan dan intensitas interaksi dengan lingkungan dan masyarakat lokal. Berdasarkan fakta di atas maka perlu dirumuskan bentuk pembangunan pariwisata berkelanjutan yang lebih tepat di masa mendatang. Oleh sebab itu pariwisata yang berbasis kearifan lokal pedesaan merupakan salah satu alternatif yang dapat diterapkan untuk memenuhi tuntutan tersebut.

Potensi pengembangan destinasi wisata berbasis kearifan lokal pedesaan di Bali memiliki peluang yang sangat besar untuk dikembangkan, dengan adanya kondisi alam, sosial, dan budaya masyarakatnya yang variatif. Terlebih dalam aspek religi, setiap desa di Bali tidak jarang memiliki dresta atau pakem adat istiadat yang sangat beragam. Salah satunya dapat dilihat di Desa Pedawa, Kecamatan Banjar, Kabupaten Buleleng, yang masyarakatnya telah dikenal sebagai salah satu komunitas Bali Mula atau Bali Aga.

Berbeda dari mayoritas masyarakat Bali pada umumnya, corak adat istiadat dan budaya masyarakat Bali Mula di Desa Pedawa sangatlah khas dan ikonik. Terlebih didukung dengan potensi alam yang sangat indah, menjadikan Desa Pedawa sering menjadi sasaran kunjungan wisatawan, baik untuk sekedar berkunjung hingga melaksanakan studi etnografi. Menyadari adanya fenomena tersebut, maka beberapa tokoh masyarakat dan para pemuda Desa Pedawa membentuk suatu kelompok yang dikelola secara swadaya yang bernama kelompok Kayoman Pedawa.

Kelompok Kayoman Pedawa yang diinisiasi langsung oleh masyarakat Desa Pedawa bertujuan untuk merekonstruksi dan merevitalisasi keberadaan potensi wisata berupa alam, sosial, adat istiadat dan kearifan lokal masyarakat setempat. Dibentuknya kelompok ini berawal dari keprihatinan masyarakat dan 
tokoh-tokoh muda Desa Pedawa akan fenomena semakin tergerusnya alam dan kearifan lokal seiring pesatnya modernisasi. Terlebih kemajuan ilmu pengetahuan dan teknologi merupakan faktor penyebab utama terdegradasinya pemahaman mayoritas generasi muda akan kearifan lokal setempat. Apabila tidak ditanggulangi akan berpotensi pula mendistorsi ikon-ikon pariwisata budaya yang berbasis pedesaan dan kearifan lokal yang sesungguhnya lebih diminati wisatawan dibandingkan pariwisata yang bersifat konvensional.

Eksistensi kelompok Kayoman Pedawa juga sangat fenomenal, sehingga perlu dikaji lebih mendalam. Fenomena ini disebabkan karena sesungguhnya Desa Pedawa sendiri telah memiliki Kelompok Sadar Wisata (Pokdarwis). Terlebih Desa Pedawa termasuk ke dalam 31 desa yang telah ditetapkan berpredikat Desa Wisata melalui Surat Keputusan Bupati Buleleng Nomor 430/405/HK/2017, tentang Desa Wisata Kabupaten Buleleng (Widiastini dkk, 2018). Artinya pembentukan kelompok Kayoman Pedawa sebagai bentuk langkah konservasi sekaligus revitalisasi potensi wisata di Desa Pedawa mengindikasikan adanya ranah-ranah yang belum tersentuh oleh pihak-pihak terkait, khususnya Pokdarwis.

Umumnya, gerakan sadar wisata di sejumlah daerah diwujudkan dengan adanya Pokdarwis. Artinya tugas-tugas untuk merevitalisasi potensi-potensi wisata di Desa Pedawa juga semestinya dominan menjadi tanggung jawab Pokdarwis. Terlebih Pokdarwis merupakan salah satu bentuk kelembagan informal yang keabsahannya telah diakui dan memiliki tugas pokok untuk memperkenalkan, melestarikan, dan memanfaatkan pontensi pariwisata yang dimiliki oleh desa setempat. Menurut Buku Panduan Kelompok Sadar Wisata (Firmansyah, 2012) tujuan Pokdarwis meliputi:

a. Meningkatkan posisi dan peran masyarakat sebagai subjek atau pelaku penting dalam pembangunan kepariwisataan. Serta dapat bersinergi dan bermitra dengan Stakeholders terkait dalam meningkatkan kualitas perkembangan kepariwisataan di daerah.

b. Membangun dan menumbuhkan sikap dan dukungan positif masyarakat sebagai tuan rumah melalui perwujudan nilai-nilai Sapta Pesona bagi tumbuh dan berkembangnya kepariwisataan di daerah dan manfaatnya bagi pembangunan daerah maupun kesejahteraan masyarakat.

c. Memperkenalkan, melestarikan dan memanfaatkan potensi daya tarik wisata yang ada di masing-masing daerah.

Beranjak dari hal tersebut, merupakan suatu hal yang sangat fenomenal apabila masyarakat Desa Pedawa sampai membentuk pula kelompok Kayoman Pedawa yang bersifat swadaya dan memiliki tujuan yang relatif sama dengan Pokdarwis. Fenomena ini menjadi suatu hal yang patut dikaji secara lebih mendalam mengenai peran kelompok Kayoman Pedawa dalam merevitalisasi potensi-potensi wisata di Desa Pedawa, Kecamatan Banjar, Kabupaten Buleleng. Melalui hasil penelitian ini, diharapkan dapat bermanfaat dalam menggugah kesadaran masyarakat dan insan-insan pariwisata untuk lebih aktif menggali dan merevitalisasi potensi-potensi wisata yang berbasis pedesaan dan kearifan lokal.

\section{METODE PENELITIAN}

Lokasi penelitian ini adalah Desa Pedawa, Kecamatan Banjar, Kabupaten Buleleng. Alasan dipilihnya lokasi ini adalah dengan pertimbangan bahwa Desa 
Pedawa merupakan salah satu Desa Wisata di Buleleng yang memiliki potensi wisata berbasis kearifan lokal khas Bali Aga atau Bali Mula. Selain itu, eksistensi kelompok Kayoman Pedawa dan peranannya dalam merevitalisasi potensi wisata berbasis kearifan lokal merupakan fenomena yang terjadi di Desa Pedawa sehingga perlu dikaji secara lebih mendalam. Jenis penelitian ini merupakan penelitian kualitatif, karena data yang diperoleh dalam penelitian ini tidak dicapai melalui prosedur statistik atau dengan cara kuantifikasi lainnya Pendekatan yang digunakan adalah pendekatan sosial humaniora. Pendekatan sosial humaniora dipergunakan mengungkap peranan kelompok Kayoman Pedawa dalam upaya merevitalisasi potensi wisata yang berbasis kearifan lokal.

Informan dalam penelitian ini dipilih dengan teknik purposive. Setyosari (2010), menyatakan bahwa purposive dilakukan oleh peneliti, apabila peneliti memiliki alasan-alasan khusus tertentu berkenaan dengan informan yang akan diambil. Informan dipilih berdasarkan kriteria-kriteria atau ciri-ciri tertentu yang ditentukan oleh peneliti sendiri, sehingga dapat mewakili karakteristik dari keseluruhan masyarakat selaku objek penelitian. Dalam hal ini setiap informan yang dihubungi disesuaikan dengan kriteria-kriteria tertentu yang diterapkan berdasarkan tujuan penelitian. Beberapa kriteria yang ditetapkan di antaranya yakni melihat dari hubungan antara variabel permasalahan yang diteliti dengan latar belakang informan tersebut, seperti anggota kelompok Kayoman Pedawa, tokohtokoh masyarakat Desa Pedawa, serta para wisatawan yang berkunjung ke desa tersebut. Dengan demikian diharapkan peneliti dapat memperoleh informasi yang menyeluruh terkait dengan tema penelitian dibahas.

Penelitian ini mempergunakan beberapa teknik pengumpulan data seperti observasi non-partisipan, wawancara berstruktur, dan studi kepustakaan. Teknik analisis data dalam penelitian ini adalah deskriptif kualitatif. Teknik deskriptif kualitatif adalah menafsirkan suatu gejala objektif sesuai dengan data kepustakaan maupun data lapangan yang menjadi objek penelitian. Adapun langkah-langkah yang dipergunakan dalam analisis data penelitian ini adalah reduksi data, penyajian dan penarikan kesimpulan..

Data yang sudah dikumpulkan serta dianalisis selanjutnya disajikan dengan menggunakan cara informal dan formal. Cara informal yaitu suatu cara penyajian data atau hasil penelitian dideskripsikan dengan menggunakan kata-kata (narasi) dan dan disajikan secara objektif. Cara informal dilakukan karena dari keseluruhan data yang diperoleh sebagian besar berupa kata-kata yang bersifat uraian. Sedangkan cara formal merupakan cara penyajian data yang tergolong dalam data kuantitatif berupa angka-angka. Cara formal dimungkinkan untuk dipergunakan karena sebagian kecil data ada berupa angka-angka, yang sifatnya menggambarkan gambaran umum dari lokasi penelitian yang dilakukan. Angka-angka ini disajikan dalam bentuk tabel dan dideskripsikan secara kualitatif.

\section{HASIL PENELITIAN DAN PEMBAHASAN}

Berdasarkan data-data penelitian yang diperoleh, kelompok Kayoman Pedawa rupanya telah terlebih dahulu dibentuk secara swadaya oleh beberapa tokoh masyarakat dan pemuda setempat pada tahun 2016. Ini terjadi sebelum penetapan Desa Pedawa sebagai Desa Wisata. Oleh sebab itu, kelompok Kayoman Pedawa terlebih dahulu eksis dibandingkan dengan Pokdarwis. Hanya saja, sebelum Desa 
Pedawa ditetapkan sebagai Desa Wisata, kelompok Kayoman Pedawa dibentuk hanya sebagai bentuk spontanitas, tanpa struktur yang sistematis, yang hanya diketuai oleh satu orang koordinator, yakni bapak I Putu Yuli Supriyandana. Sedangkan anggotanya terdiri dari sekitar 25 orang dari berbagai kalangan, seperti para pemuda dan tokoh-tokoh masyarakat yang peduli dengan berbagai kekayaan budaya dan kearifan lokal yang dimiliki oleh Desa Pedawa.

Orang-orang yang tergabung dalam kelompok tersebut memiliki berbagai keahlian dan minat khusus, misalnya budayawan, sejarawan, agamawan, fotografer, ahli bahasa daerah, dan lain sebagainya. Tujuannya saat itu hanya satu, yakni mengupayakan agar Desa Pedawa tidak kehilangan kearifan lokalnya yang mulai pudar oleh perkembangan jaman serta memperoleh predikat Desa Wisata. Dengan adanya wisatawan yang datang, diharapkan tumbuh rasa bangga pada generasi muda akan identitas dirinya sebagai orang asli Desa Pedawa.

Pada perkembangannya, setelah predikat Desa Wisata diperoleh dan terbentuknya Pokdarwis pada tahun 2017, eksistensi kelompok ini tetap dipertahankan atas usulan dari para tokoh-tokoh adat setempat. Alasannya karena kelompok ini dipandang sangat aktif dan telah mendapat apresiasi yang luar biasa dari para tetua-tetua adat dan para budayawan setempat, sehingga dipandang perlu dipertahankan. Menyikapi hal tersebut, maka eksistensi kelompok Kayoman Pedawa dikukuhkan dibawah perlindungan desa adat, yakni Desa Pakraman Pedawa dan juga Desa Dinas Pedawa. Dibentuklah struktur kepengurusan sebagaimana digambarkan dalam bagan berikut.

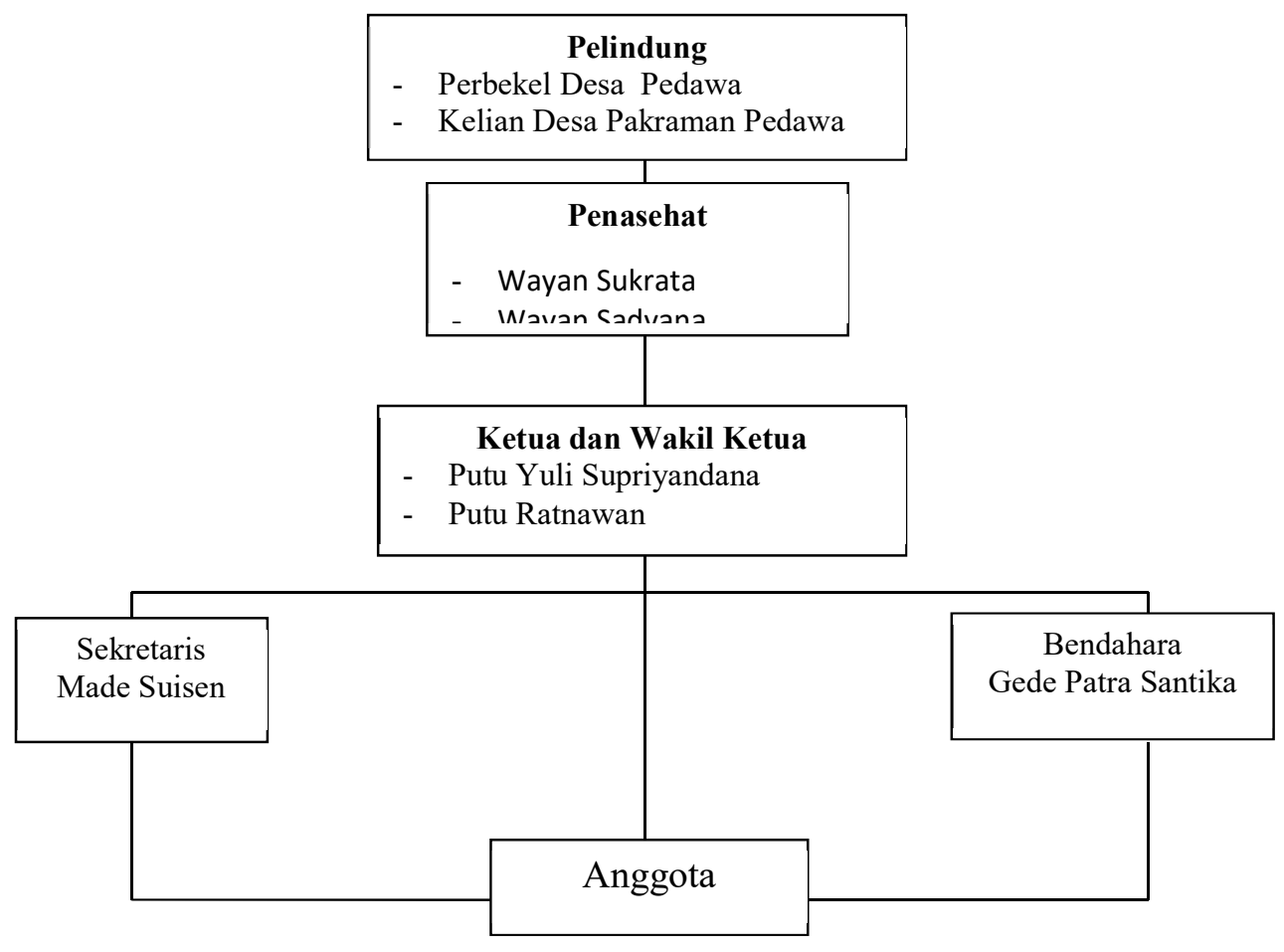

Gambar 1. Struktur Kepengurusan Kelompok Kayoman Pedawa Sumber: Profil AD ART Kelompok Kayoman Pedawa 
Kelompok Kayoman Pedawa dalam bekerja murni menerapkan konsep ngayah, dalam arti tidak dibayar atau sama sekali tidak mendapatkan kompensasi finansial apapun. Malahan terkadang jika kekurangan dana, secara sukarela para anggota akan urunan semampunya demi terlaksananya program-program kegiatan yang telah dirumuskan. Terkait dengan hal tersebut, peranan Kelompok Kayoman Pedawa dalam merevitalisasi potensi wisata berbasis kearifan local di Desa Pedawa dapat diuraikan sebagai berikut.

\section{A. Rehabilitasi Hutan dan Budaya Agrikultur}

Rehabilitasi hutan dan budaya agrikultur merupakan hal yang pertama dan paling prioritas untuk diprogramkan dan dilaksanakan oleh kelompok Kayoman Pedawa. Hal ini berkaitan dengan keyakinan masyarakat bahwa alam merupakan pondasi utama dari kearifan lokal. Terlebih masyarakat Desa Pedawa merupakan masyarakat yang pola kebudayaannya berbasis agrikultur. Mengutip pernyataan dari Liliweri (2009), faktor unsur-unsur ekosistem yang merupakan pembentuk variabilitas antar-budaya yang utama, secara rinci dapat diuraikan bahwa:

a. Faktor-faktor ekosistem membatasi kebudayaan.

b. Unsur-unsur eksternal dari ekosistem tersebut membiarkan kemungkinan bagi berkembangnya sebuah kebudayaan.

c. Unsur-unsur ekosistem eksternal tersebut membuat manusia menciptakan atau membuat sesuatu yang sesuai bagi kehidupannya.

d. Dalam mengembangkan kebudayaan, maka manusia diberi kesempatan untuk memilih dan bahkan cenderung untuk menyesuaikan diri dengan ekosistem.

e. Unsur-unsur eksternal dari ekosistem dapat diubah oleh cara-cara kebudayaan tertentu.

Terkait dengan hal tersebut, upaya penyelamatan ekosistem merupakan program utama yang diprioritaskan oleh kelompok Kayoman Pedawa, karena setelah dilakukan observasi, banyak kerusakan yang terjadi akibat eksploitasi kayukayu hutan tersebut. Hal tersebut dikhawatirkan berdampak pada mengecilnya sumber air. Disamping itu, kekhawatiran lain yang timbul adalah mengancam eksistensi dari ekowisata yang juga tengah giat-giatnya dikembangkan. Dengan kata lain, penyelamatan hutan dan ekosistem merupakan langkah awal yang harus dilakukan sebagai bagian dari konservasi dan revitalisasi kearifan lokal setempat.

Menurut Wijana (2014), luas hutan di Desa Pedawa adalah 8,56 ha dan memiliki perkebunan seluas 85,106 ha, serta lahan pertanian seluas 10,15 ha. Lahan pertanian umumnya ditanami padi dan padi gaga. Sedangkan lahan perkebunan umumnya ditanami dengan cengkeh dan kopi, serta pohon aren. Pohon aren dipelihara karena masyarakat Desa Pedawa memiliki produk lokal berupa gula aren yang sangat terkenal di Kabupaten Buleleng. Umumnya masyarakat Buleleng sangat mengenal produk gula aren tersebut dengan nama Gula Pedawa, sehingga secara tidak langsung produk gula aren produksi Desa Pedawa sudah disematkan menjadi identitas kearifan lokal setempat. Terlebih proses pembuatannya kebanyakan masih mengandalkan cara-cara tradisional. Hanya saja tradisi tersebut mulai ditinggalkan, karena secara ekonomis tidak terlalu menguntungkan jika dibandingkan dengan cengkeh, sehingga banyak yang beralih pada pembudidayaan cengkeh. Disamping itu, minat generasi muda terhadap cara-cara pembuatan gula tradisional dengan proses yang cukup panjang sudah mulai menurun. Dampaknya 
pohon-pohon aren yang dulunya berjumlah banyak, kini mulai berkurang karena diganti dengan cengkeh atau kopi yang dianggap lebih menguntungkan.

Berdasarkan hal tersebut, maka Kelompok Kayoman Pedawa berupaya untuk melakukan rehabilitasi hutan dengan melakukan penanaman pohon-pohon berkayu keras, termasuk juga pohon jaka atau aren. Pelaksanaan kegiatan tersebut dapat dilihat dalam gambar berikut.

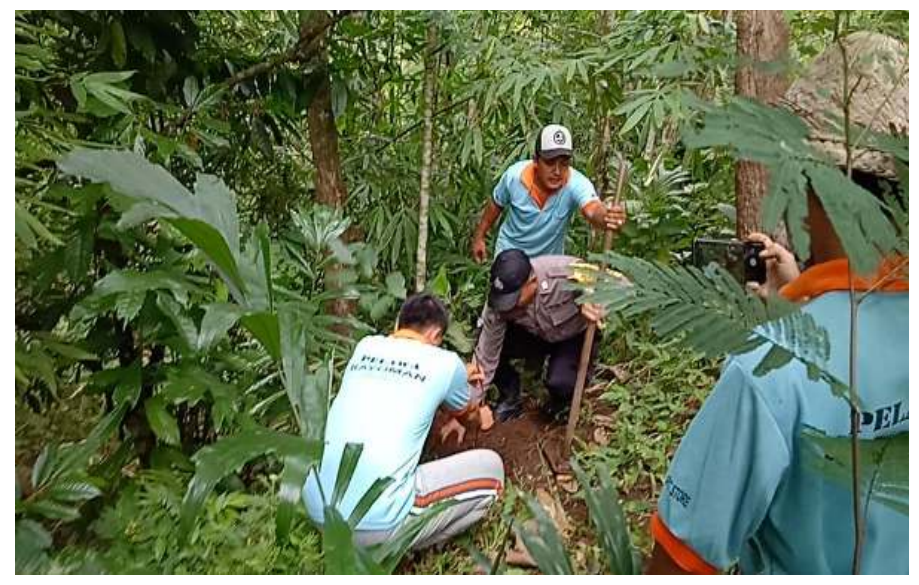

Gambar 2. Penanaman Pohon di Hutan Desa Pedawa oleh Kelompok Kayoman Pedawa

Dok. Supriyandana,14 Februari 2019.

Pohon-pohon yang ditanam biasanya terdiri dari pohon aren (arenga pinnata), cempaka (michelia alba), majegau (dysokxylum densiflorum), dan nangka (artocaprus heterophyllus), dan tanaman-tanaman lain yang berkayu keras. Umumnya tanaman yang dipilih diupayakan tidak hanya sekedar berkayu keras, namun juga dapat dimanfaatkan oleh masyarakat, terutama pohon aren untuk jangka panjang yang dimanfaatkan sebagai bahan baku pembuatan gula merah.

Program penanaman pohon dirancang setahun dua kali dengan memperhatikan ketersediaan bibit yang diperoleh. Bibit diperoleh kebanyakan melalui bantuan dari Dinas Lingkungan Hidup Kabupaten Buleleng, beberapa organisasi pecinta lingkungan, maupun swadaya masyarakat. Disamping untuk merevitalisasi kearifan lokal Desa Pedawa, pelestarian dan reboisasi hutan desa juga diprospek kedepannya agar mampu mewujudkan destinasi wisata yang berbasis hutan pedesaan.

\section{B. Revitalisasi Peninggalan Purbakala menjadi Destinasi Wisata Sejarah Desa}

Desa Pedawa merupakan desa yang sudah sangat tua keberadaannya. Menurut penuturan para tetua adat setempat, yang sekaligus juga menjadi penasihat Kelompok Kayoman Pedawa, wilayah Desa Pedawa yang sekarang dulunya telah dihuni manusia sejak zaman megalitikum. Hal ini dibuktikan dengan penemuanpenemuan sarkofagus (peti kubur batu) yang lazim dipergunakan pada zaman megalitikum. Total jumlah sarkofagus yang ada di Desa Pedawa mencapai 7 (tujuh) buah, 5 (lima) diantaranya dalam kondisi utuh, namun yang 2 (dua) lagi dalam kondisi rusak. Penemuan 5 sarkofagus awalnya terjadi secara tidak sengaja di 
lahan-lahan perkebunan warga, sedangkan yang 2 lagi merupakan temuan dari hasil pencarian yang sengaja dilakukan masyarakat yang pada tahun 2009 lalu.

Terkait dengan hal tersebut, Kelompok Kayoman Pedawa merupakan kelompok yang menginisiasi pemetaan peninggalan-peninggalan purbakala tersebut. Hal ini dilakukan karena adanya fenomena bahwa masyarakat Desa Pedawa mensakralkan sarkofagus tersebut secara Hindu, sehingga meskipun sudah sejak sekian lama ditemukan, temuan itu baru bisa resmi didaftarkan ke Dinas Kebudayaan Kabupaten Buleleng pada tahun 2018 yang lalu. Sebelumnya masyarakat umum, meskipun mengizinkan pihak luar untuk melihat-lihat, namun cukup sulit untuk menyentuhnya, apalagi mengadakan penelitian secara seksama akibat sikap masyarakat yang konservatif. Sarkofagus tersebut dapat dilihat dalam gambar berikut.
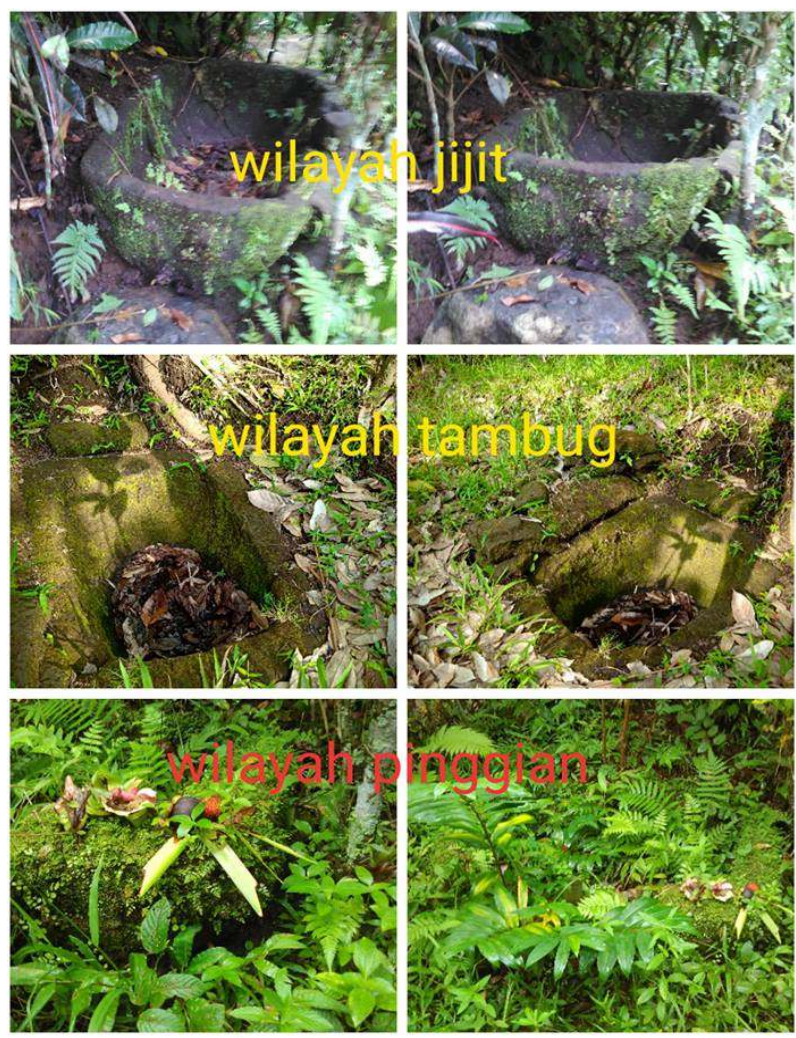

Gambar 3. Sarkofagus Peninggalan Purbakala Desa Pedawa

Dok. Supriyandana, 2018 


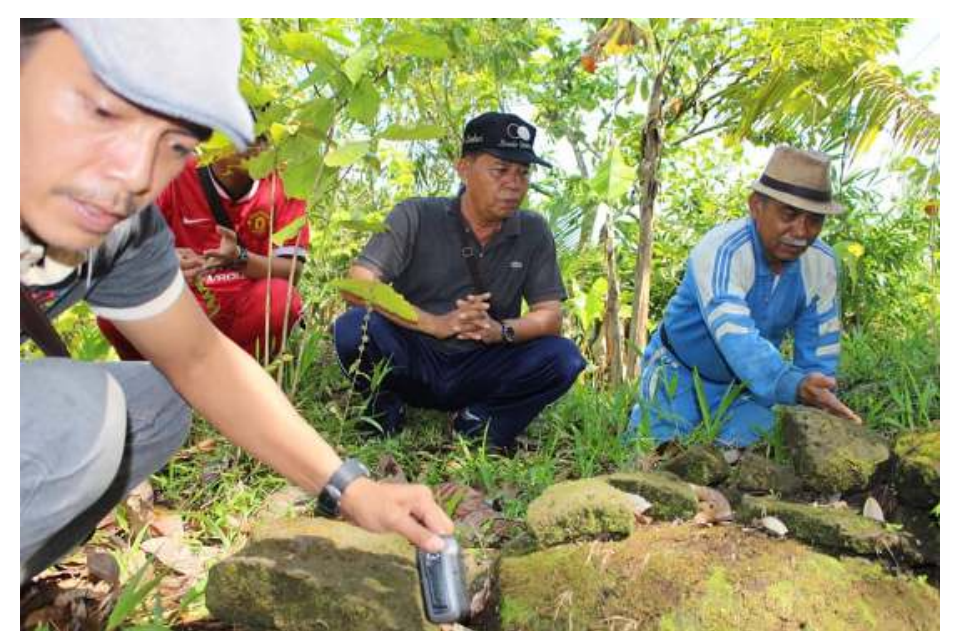

Gambar 4. Pemetaan Sarkofagus Oleh Kelompok Kayoman Pedawa Dengan Menggandeng Dinas Kebudayaan Kabupaten Buleleng Dok. Dinas Kebudayaan Kabupaten Buleleng, 2018

Kelompok Kayoman Pedawa saat ini telah mengupayakan untuk memetakan ulang sarkofagus-sarkofagus tersebut melalui pendekatan persuasif kepada masyarakat. Disamping itu kerjasama dengan pihak Dinas Kebudayaan Kabupaten Buleleng juga dilakukan secara intensif. Tujuannya disamping pelestarian dengan memasukkan peninggalan tersebut menjadi warisan cagar budaya, juga mengupayakan agar mampu dijadikan museum desa dan menjadi tujuan wisata sejarah desa.

\section{a. Rekonstruksi Atraksi Berbasis Kearifan Lokal}

Sebagai sebuah desa yang memiliki komunitas masyarakat yang sudah mulai berpikiran modern, maka konsekuensinya adalah adanya beberapa aspek kebudayaan lokal yang mengalami degradasi. Degradasi tersebut menandakan arus ilmu pengetahuan dan teknologi yang telah maju, namun di sisi lain beberapa aspek kearifan lokal yang sesungguhnya dapat dijadian aset wisata mulai luntur keberadaannya.

Beranjak dari hal tersebut, Kelompok Kayoman Pedawa telah melakukan sejumlah langkah-langkah penyelamatan melalui upaya rekonstruksi. Beberapa contoh kearifan lokal yang berhasil direkonstruksi atas upaya yang diinisiasi oleh tokoh-tokoh masyarakat yang tergabung dalam Kelompok Kayoman Pedawa dapat diuraikan sebagai berikut.

1. Rumah dan Pakaian Tradisional Pedawa

Rumah adat khas kearifan lokal Desa Pedawa disebut dengan Rumah Adat Bandung Rangki. Dulunya setiap keluarga di Desa Pedawa konstruksi bangunannya berbasis rumah adat tradisional yang sama. Namun seiring perkembangan arus modernisasi, maka eksistensi Rumah Adat Bandung Rangki hilang keberadaannya. Melihat fenomena tersebut, Kelompok Kayoman Pedawa kemudian mengadakan rekonstruksi untuk menghadirkan kembali Rumah Adat Bandung Rangki. Bahkan salah seorang dari penasehat Kelompok Kayoman Pedawa, yakni bapak Wayan Sukrata bersedia tanah kebunnya seluas kurang lebih 5 are dipergunakan untuk keperluan tersebut. Hasilnya, berdasarkan rekonstruksi yang dilakukan dengan berpedoman pada ingatan-ingatan tetua-tetua adat zaman dahulu, maka satu Rumah 
Adat Bandung Rangki telah berdiri. Tidak hanya tampilan luarnya, melainkan lengkap dengan berbagai ornamen-ornamen tradisional di dalamnya seperti dapur tradisional, tempat tidur, dan segala macam peralatan rumah tangga yang tradisional. Tampilan Rumah Adat Bandung Rangki tampak dalam gambar berikut.

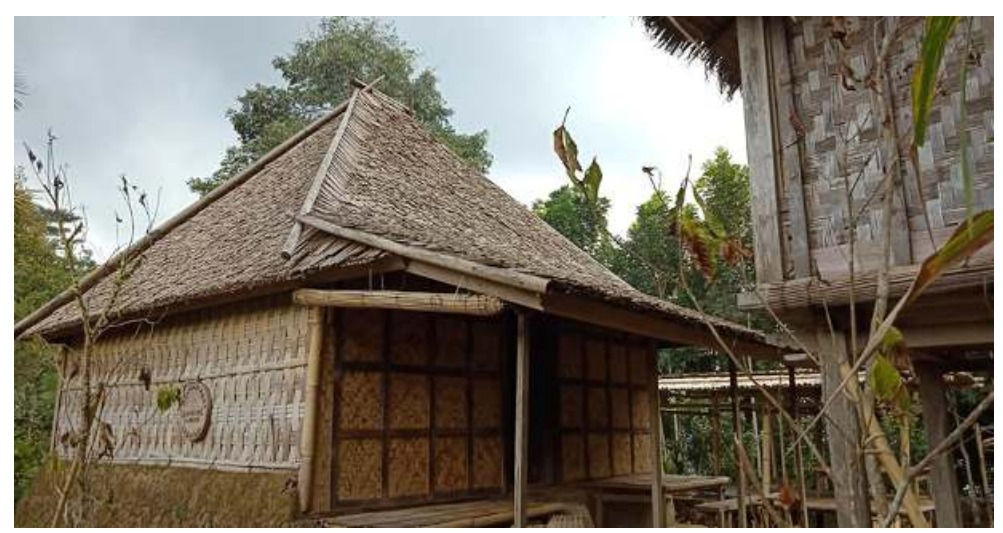

Gambar 5. Rumah Adat Bandung Rangki Tampak Dari Luar Dok. Jayendra, 2019

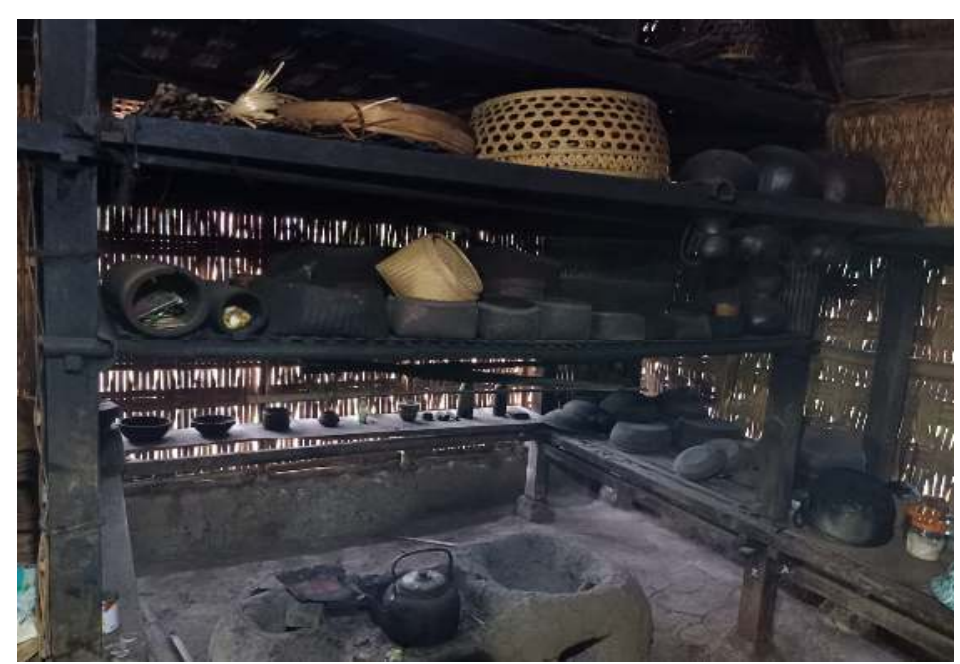

Gambar 6. Isi Bagian Dalam Rumah Adat Bandung Rangki

Dok. Jayendra, 2019

Bagi pengunjung yang datang mengunjungi rumah adat tersebut dapat pula mengenakan pakaian tradisional masyarakat Pedawa. Kebetulan saat penelitian ini berlangsung, Desa Pedawa mendapat kunjungan dari Dinas Pariwisata Kabupaten Buleleng yang menggandeng Putri Pariwisata Indonesia tahun 2019 (Devi Septyani) beserta Jegeg Buleleng 2019. Kunjungan tersebut sekaligus juga menyempatkan diri untuk berpose mengenakan pakaian tradisional Pedawa (diperagakan oleh Ketua Kelompok Kayoman Pedawa berpasangan dengan Jegeg Buleleng 2019) dengan latar belakang Rumah Adat Bandung Rangki sebagaimana tampak dalam gambar berikut. 


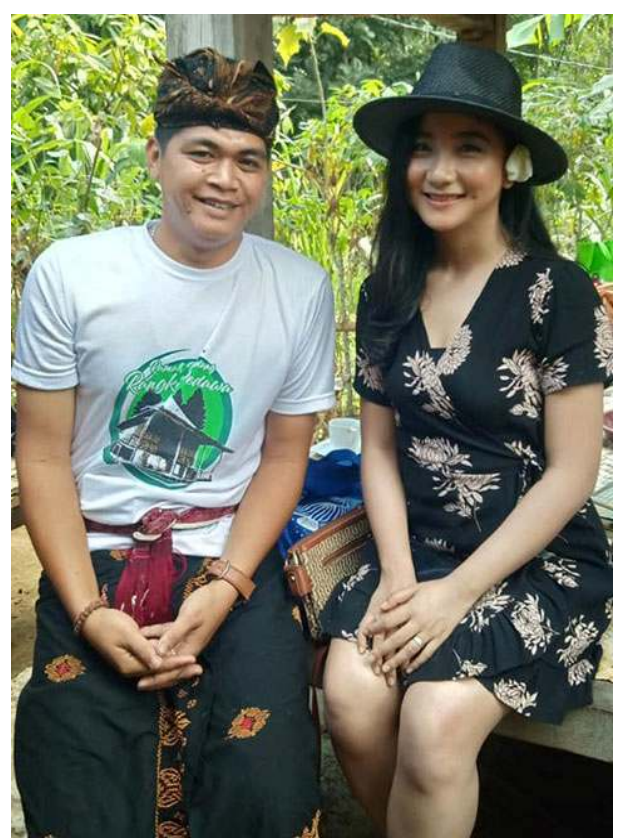

Gambar 7. Kunjungan Putri Pariwisata Indonesia 2019 ke Desa Pedawa Dok. Jayendra 2019

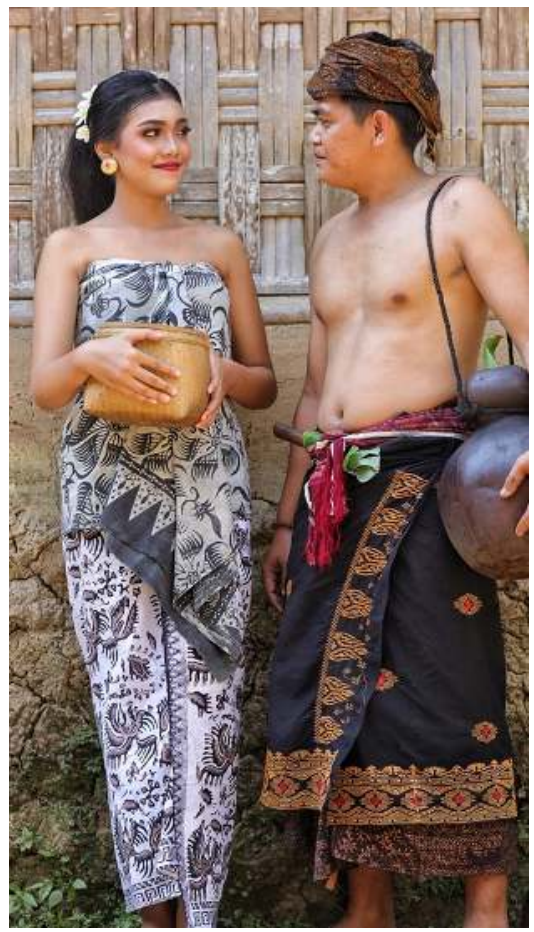

Gambar 8. Peragaan Busana Tradisional Pedawa Oleh Ketua Kelompok Kayoman Pedawa dan Jegeg Buleleng 2019

Dok. Jayendra 2019

Rumah Adat Bandung Rangki beserta pakaian tradisional Pedawa kini telah menjadi satu destinasi wisata berbasis kearifan lokal yang ikonik di Desa Pedawa. 
Bahkan sering dijadikan objek studi oleh para mahasiswa yang ingin mempelajari kearifan lokal Desa Pedawa, termasuk pula tercatat beberapa mahasiswa asing dari Jepang. Hingga saat ini bagi para wisatawan yang memasuki areal rumah adat Bandung Rangki ini tidak dikenakan biaya apapun, hanya sebatas sumbangan sukarela (punia) seikhlasnya. Dana yang terkumpul akan dipergunakan untuk membantu pemeliharaan rumah adat tersebut serta menunjang kegiatan-kegiatan lainnya yang diprogramkan oleh Kelompok Kayoman Pedawa.

2. Permainan Gangsing Tradisional

Gangsing merupakan bahasa Bali yang artinya gasing. Dalam bahasa Bali, memainkan gasing disebut magangsing. Gangsing adalah mainan atau permainan yang dapat berputar pada satu poros berkesetimbangan pada satu titik. Permainan gangsing tradisional di Bali merupakan permainan yang sudah berumur sangat tua. Gangsingnya terbuat dari kayu seperti kayu cemara, limau atau kayu kemuning. Bahan baku kayu sendiri diperoleh dari sekitar desa atau juga dari luar desa.

Permainan gangsing tradisional sesungguhnya bukan hanya milik Desa Pedawa, namun juga desa-desa lain di sekitarnya seperti Desa Gobleg, Desa Munduk, Desa Gesing, dan Desa Umajero. Namun pada masa kini permainan gangsing tradisional sudah jarang dimainkan. Bahkan dalam website resmi Pemerintah Kabupaten Buleleng sendiri telah menyatakan bahwa permainan gangsing sudah tidak banyak dikenal pada masyarakat, kecuali pada suatu daerah tertentu karena terkait dengan tradisi tertentu. Bahkan dapat dikatakan permainan ini hampir punah di Bali (https://bulelengkab.go.id/detail/artikel/permainangangsing-33, diakses 29 Juli 2019).

Permainan gangsing tradisional dilakukan dengan melilitkan tali pada bagian atas gangsing, kemudian dilemparkan sehingga berputar karena ditarik kembali setelah dilemparkan sehingga berputar mengikuti ikatan tali tersebut. Tali dipergunakan berbahan kulit kayu atau tali tambang yang diikal sesuai dengan kebutuhan besarnya gangsing.

Lomba gangsing dilakukan berkelompok, bukan perorangan. Oleh karena itu dalam lomba tidak menggunakan satu gangsing tetapi lebih dari satu. Kelompok pertama melepas gangsingnya, kemudian kelompok dua ngebug/ memukulnya dengan gangsing pula, kemudian dibiarkan berputar. Gangsing kelompok mana yang lebih lama berputar yang menjadi pemenangnya. Permainan ini digelar di atas tanah padat yang dibuatkan kalangan. Dalam permainan ini diperlukan ketangkasan/ketrampilan memutarkan gangsing, kesempurnaan bentuk gangsing, dan kekuatan fisik dalam memutarkan gangsing.

Permainan ini dulunya juga ada di Desa Pedawa. Namun dengan adanya modernisasi dan perubahan pola pikir generasi mudanya, maka sudah cukup lama (dalam hitungan tahun) permainan ini tidak dimainkan lagi. Kelompok Kayoman Pedawa yang telah mengamati bahwa permainan tradisional ini mulai tergerus kemudian bergerak secara aktif untuk membangkitkannya kembali. Adapun langkah-langkah yang dilakukan antara lain; Melakukan semacam studi banding dengan melihat permainan gangsing tradisional masih dipertahankan di beberapa sekitarnya, seperti Desa Gobleg dan Desa Munduk. Dari pengamatan yang dilakukan, kemudian dicatat hal-hal yang dirasa penting, yang umumnya menyangkut tentang jumlah kelompok, aturan permainan, pemberian point, dan lain sebagainnya. Dalam kegiatan ini, umumnya yang ditugaskan adalah anggota kelompok yang muda-muda. Selanjutnya melakukan penggalian informasi dari para 
penduduk Desa Pedawa yang dulunya pernah melakukan permainan tersebut. Informasi-informasi yang diperoleh merupakan modal yang penting dalam membangkitkan kembali permainan tersebut.

Langkah berikutnya adalah melakukan rekonstruksi permainan gangsing tradisional. Dalam kegiatan ini, para anggota kelompok Kayoman Pedawa belajar memainkan gangsing dan bermain simulasi dalam lingkup intern kelompok. Gangsing yang digunakan awalnya diperoleh dari hasil memesan atau membeli ke Desa Munduk yang masih memiliki tokoh-tokoh pengrajin gangsing, setelah itu, kelompok ini juga turut menginisiasi pembentukan kelompok sekaa gangsing Desa Pedawa. Sekaa gangsing Desa Pedawa pada awalnya didirikan tahun 2016 dan anggotanya hanya terdiri dari anggota kelompok Kayoman Pedawa. Namun berkat intensitas kegiatan rekonstruksi yang dilakukan akhirnya menarik minat masyarakat dari luar kelompok untuk ikut menghidupkan kembali permainan tersebut. Kini dalam satu Desa Pedawa saja telah memiliki tiga sekaa gangsing.

Untuk pertama kalinya, sekaa gangsing di Desa Pedawa berpartisipasi dalam kegiatan pentas seni budaya Desa Pedawa yang digelar bulan Juli tahun 2019. Dalam kegiatan pentas seni budaya Desa Pedawa yang diinisiasi oleh tokohtokoh adat yang bekerjasama dengan Pokdarwis dan juga kelompok Kayoman Pedawa. Dalam kegiatan ini diperkenalkan pula permainan gangsing tradisional ini oleh sekaa-sekaa gangsing yang ada di Desa Pedawa. Kegiatan ini mendapat apresiasi dari masyarakat dan wisatawan yang hadir. Kegiatan tersebut tampak dalam gambar berikut.

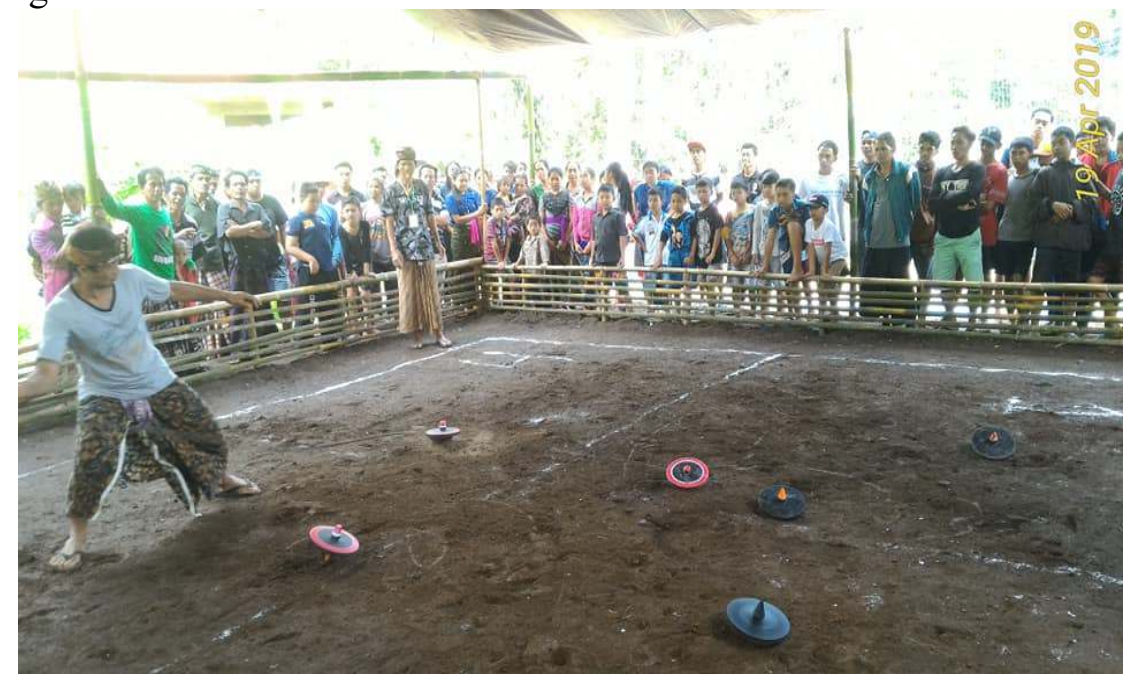

Gambar 9. Peragaan Permainan Gangsing Tradisional Desa Pedawa Dok. Supriyandana, 2019

Permainan gangsing ini direncanakan untuk dibuatkan event tahunan antar sekaa gangsing di Desa Pedawa. Bahkan untuk ke depannya, kelompok Kayoman Pedawa beserta sekaa-sekaa gangsing telah menyusun program dan berkoordinasi dengan desa-desa sekitarnya untuk dapat berpartisipasi dalam penyelenggaraan turnamen gangsing setiap tahunnya.

3. Rekonstruksi Gamelan Tradisional Pedawa

Gamelan tradisional Desa Pedawa disebut juga Tingklik Pedawa. Berbeda dari gamelan tingklik yang sudah umum dikenal di Bali, Tingklik Pedawa yang 
terbuat dari bambu memiliki 8 (delapan) plawah (bilah nada) yang ukuran bilahnya relatif besar. Menurut penuturan Supriyandana selaku Ketua Kelompok Kayoman Pedawa, Tingklik Pedawa yang sesungguhnya bersifat sakral dan tidak boleh sembarangan dimainkan. Terlebih tingklik tersebut ditempatkan di Pura Desa setempat. Namun melihat implikasi dari tidak diperbolehkan dimainkan tersebut, banyak anak-anak muda setempat yang tidak berminat memainkannya, sehingga Tingklik Pedawa cenderung hanya dimainkan oleh orang-orang tua saja. Oleh karena itulah dibuat replika tingklik tersebut yang awalnya ditujukan untuk latihan, serta menumbuhkan kecintaan para pemuda setempat akan Tingklik Pedawa. Tujuan jangka panjangnya adalah agar ada regenerasi dari penabuh Tingklik Pedawa yang sakral.

Pada perkembangannya, aktivitas latihan gamelan tingklik ini justru menarik wisatawan, baik lokal maupun mancanegara. Oleh sebab itulah kemudian latihan menabuh Tingklik Pedawa kemudian dipusatkan di Rumah Adat Bandung Rangki untuk menguatkan nuansa kearifan lokal Desa Pedawa, sebagaimana tampak dalam gambar berikut.

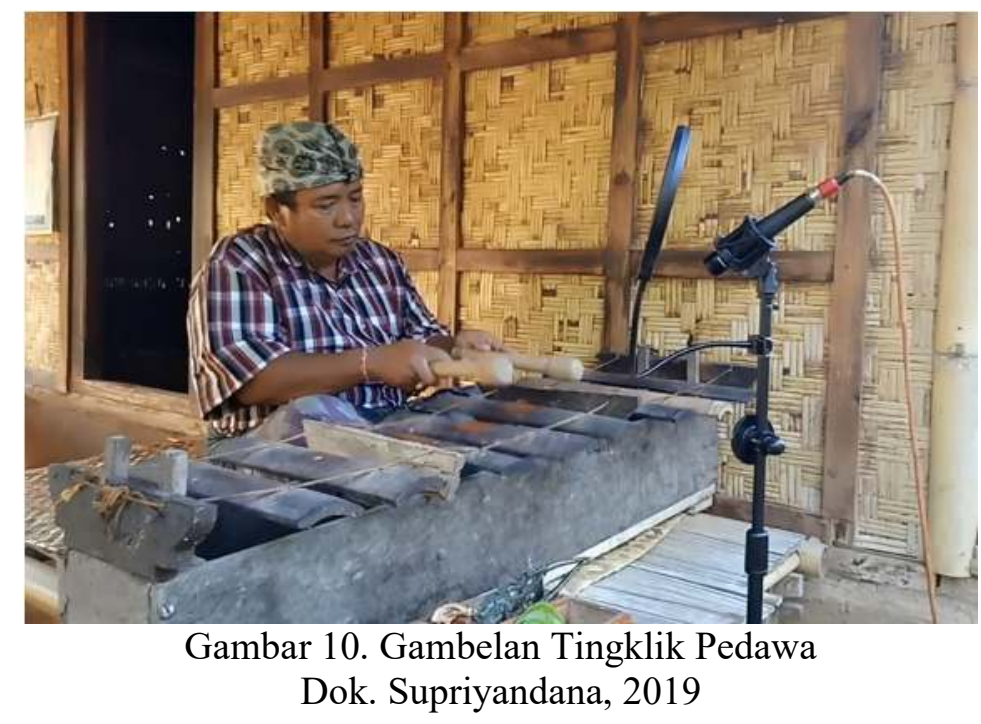

Antusiasme para pengunjung yang datang untuk melihat dan mempelajari, termasuk studi yang mendalam tentang etnografi Desa Pedawa sesungguhnya diluar perkiraan. Hal ini berimplikasi pada semakin banyaknya pemuda Pedawa yang berminat belajar memainkannya. Hal ini menandakan semakin tumbuhnya motivasi dan kecintaan para pemuda Desa Pedawa untuk melestarikannya.

4. Revitalisasi Pembuatan dan Produk Gula Aren Pedawa

Salah satu produk lokal Desa Pedawa yang cukup terkenal di Kabupaten Buleleng adalah gula aren. Gula aren produksi lokal masyarakat Desa Pedawa dikenal memiliki rasa manis alami yang khas dan berbeda dari produk gula aren atau gula merah lainnya. Proses pengolahannyapun selama ini kebanyakan masih menggunakan peralatan dan teknik tradisional, mulai dari proses penyadapan nira aren sampai pada pengolahan dan pencetakannya. Adapun peralatan dan hasil cetak gula aren Pedawa dapat dilihat dalam gambar berikut. 


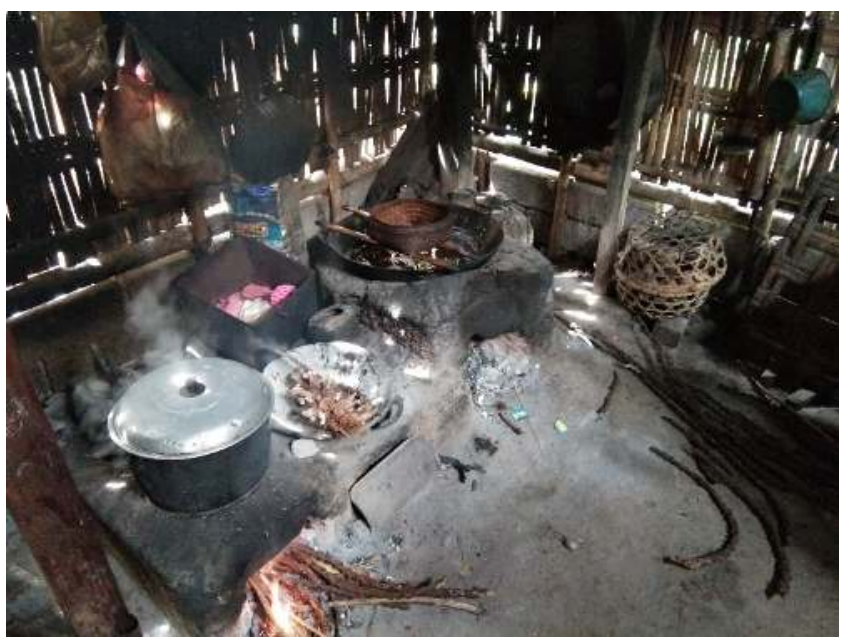

Gambar 11. Peralatan Tradisional Untuk Membuat Gula Pedawa Dok. Jayendra, 2019.

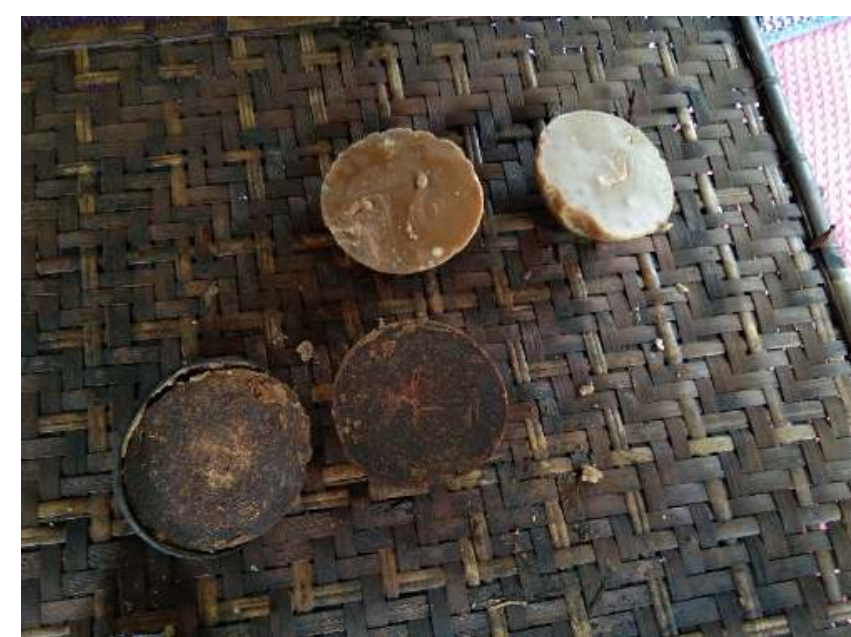

Gambar 12. Produk Gula Pedawa Hasil Olahan Tradisional

Dok. Jayendra, 2019.

Produk gula Pedawa ini awalnya dikenal oleh masyarakat Buleleng hanya secara door to door, artinya cerita dari satu individu ke individu yang lainnya. Masyarakat luar yang ingin mencari gula Pedawa kebanyakan langsung datang ke Desa Pedawa dan bertransaksi langsung dengan pembuatnya. Permasalahannya adalah produksi gula Pedawa telah mengalami penurunan akibat keuntungan yang dirasa tidak sepadan dengan proses yang panjang. Untuk memenuhi permintaan dalam intern masyarakat Desa Pedawa saja masih dirasa kurang, apalagi jika ada masyarakat luar yang ingin membelinya. Terlebih para generasi muda setempat sudah banyak yang tidak berminat melanjutkan pembuatan gula Pedawa dengan cara tradisional. Fenomena ini disebabkan umumnya karena lebih tertarik pada mata pencaharian sektor lain yang dirasa lebih menjanjikan.

Sesungguhnya kelompok yang menangani pembuatan gula Pedawa telah ada, yaitu kelompok BIMA DEWA (Bumi Perthiwi Mesawi Aren Desa Pedawa), yang terbentuk tanggal 17 Januari 2016. Namun melihat permasalahan tersebut, 
kelompok Kayoman Pedawa merespons dengan melakukan pendekatan sekaligus kerjasama untuk membantu mempopulerkan gula Pedawa. Akhirnya disepakati bahwa gula Pedawa, disamping tetap dipertahankan bentuk tradisionalnya, juga dibuatkan beberapa inovasi, termasuk dikemas secara menarik dan bergaya modern. Beberapa inovasi tersebut antara lain:

a. Gula Semut, yaitu gula aren yang telah dibuat bubuk atau serbuk halus.

b. Permen Gula Pedawa, yaitu gula aren yang dipotong kotak-kotak kecil dan dikemas dengan ukuran sebanding dengan kotak korek api.

c. Gula Juruh, yaitu gula cair yang sangat kental, cocok untuk selai roti dan pemanis kue-kue tradisional Bali.

Gula Pedawa sejak dahulu dibuat dari $100 \%$ sari aren murni. Agar lebih bergaya modern serta menghilangkan kesan kuno, maka pengemasannya dibuat semenarik mungkin, sebagaimana tampak beberapa contoh produk dalam gambar berikut.

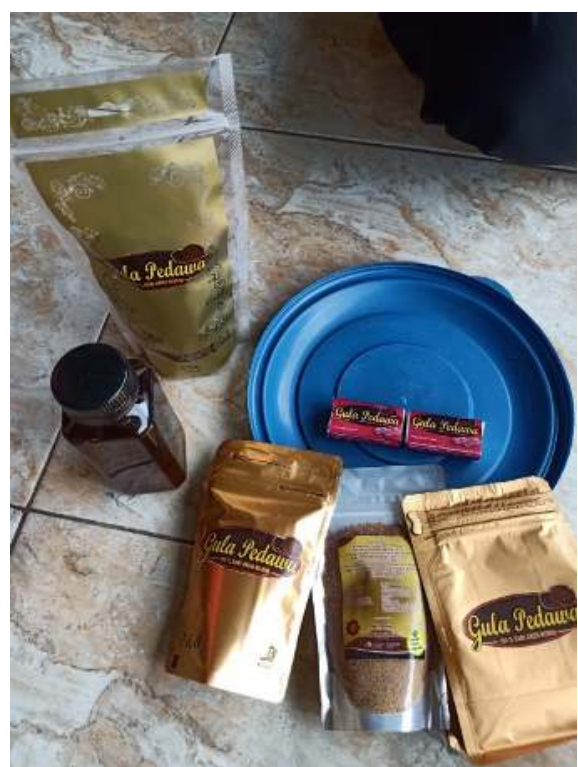

Gambar 13. Beberapa Contoh Produk Gula Aren Pedawa yang Telah Dikemas Dok. Sudarmawan, 2019

Produk Gula Pedawa yang telah dikemas ini telah dipopulerkan dalam beberapa media sosial yang dimiliki para anggota kelompok Kayoman Pedawa, serta dipromosikan pula dalam festival rutin agenda tahunan Pemerintah Kabupaten Buleleng, yaitu BULFEST (Buleleng Festival). Hanya saja produk gula Pedawa hingga saat ini masih terkendala dalam kuantitas produksi dan promosi ke luar wilayah Buleleng, sehingga diperlukan langkah-langkah lanjutan terkait dengan hal tersebut.

5. Memberikan Pendampingan Mahasiswa Asing Yang Studi Etnografi

Keunikan budaya dan kearifan lokal Desa Pedawa tidak saja mengundang minat wisatawan untuk sekedar berkunjung dang melihat-lihat. Lebih dari itu, keunikan budayanya juga sering mengundang ketertarikan mahasiswa asing yang ingin studi etnografi secara lebih mendalam. Tercatat dari akhir tahun 2018 hingga pertengahan tahun 2019 sudah ada sekitar 13 (tiga belas) mahasiswa asal Jepang yang tinggal sementara di Desa Pedawa untuk mempelajari kearifan lokal setempat. 
Mahasiswa-mahasiswa asal Jepang tersebut berasal dari beberapa perguruan tinggi di Jepang seperti Toyo University, Tokyo Institute of Teknology, Yayasan Rhissi Juku, dan yang lainnya.

Para mahasiswa asal Jepang tersebut umumnya mempelajari budaya dan kearifan lokal Pedawa yang mencakup bahasa, ekologi, dan kebiasaan-kebiasaan masyarakat setempat. Kegiatan mahasiswa asal Jepang tersebut di Desa Pedawa dapat dilihat dalam gambar berikut.

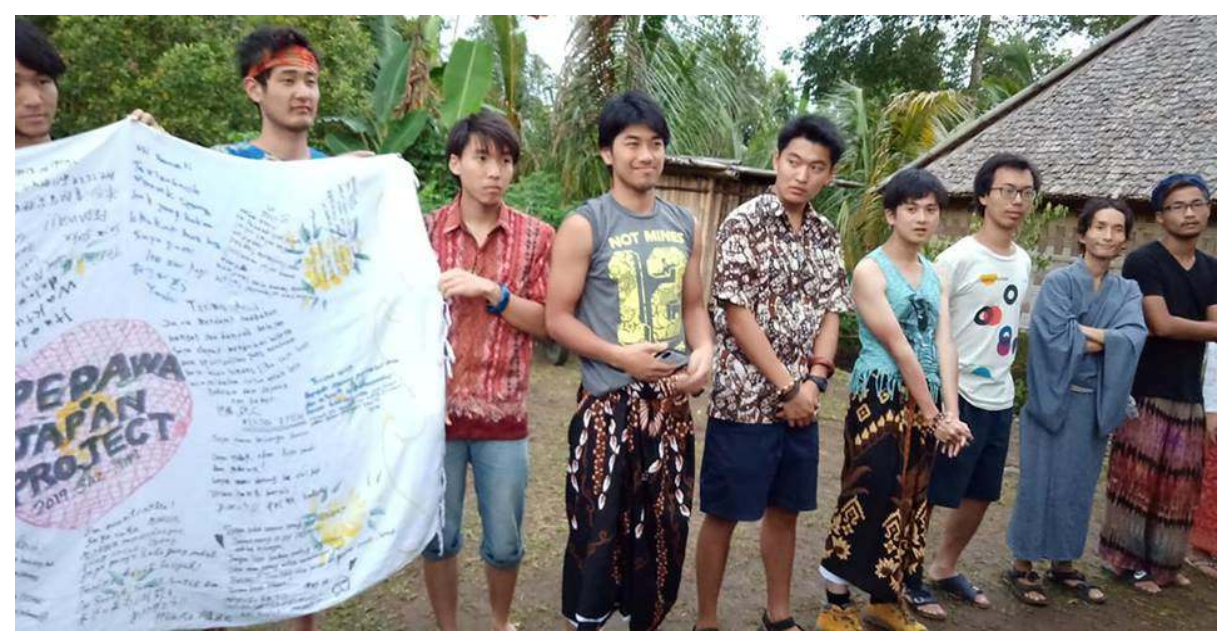

Gambar 14. Kelompok Mahasiswa Asal Jepang yang Studi di Desa Pedawa Sumber: Dok. Supriyandana, 2019

Terkait dengan hal tersebut, kelompok Kayoman Pedawa mengambil peran dalam memfasilitasi dan menjadi pemandu para mahasiswa asal Jepang tersebut selama berada di Desa Pedawa. Secara sukarela beberapa anggotanya mempersilahkan rumahnya sebagai tempat menginap selama proses melaksanakan riset. Para anggota kelompok Kayoman Pedawa sekaligus juga bertindak sebagai pemandu, mulai dari mengantar tracking menyusuri alam dan hutan Pedawa, dan sekaligus juga memberikan pendampingan sebagai sumber informasi-informasi yang sekiranya dibutuhkan terkait dengan kebudayaan setempat. Hal ini diperlukan mengingat diantara anggota kelompok tersebut merupakan orang orang terpelajar seperti guru agama, budayawan, dan lainnya. Tujuannya adalah agar tidak memberikan informasi yang salah terkait dengan kearifan lokal setempat, sehingga informasi yang didapatkan dapat dipertanggungjawabkan kebenarannya.

Peranan Kelompok Kayoman Pedawa dirasakan sangat membantu proses studi para mahasiswa asal Jepang tersebut. Bahkan koordinator kelompok mahasiswa tersebut yang bernama Mitsuha Abe mengungkapkan perasaannya sebagaimana dikutip laman tulisan populer http://www.tatkala.co (diakses 21 Agustus 2019) dengan ungkapan "aku nau gati di Pedawa" (saya sangat senang di Pedawa). Hal ini berkat adanya pendampingan secara intensif yang dilakukan Kelompok Kayoman Pedawa, sehingga proses belajar kebudayaan dan kearifan lokal Desa Pedawa yang dilakukan mampu diselesaikan dengan baik. 


\section{b. Sosialisasi dan Publikasi Kearifan Lokal Desa Pedawa Kepada Masyarakat Luar}

Sosialisasi dan publikasi kearifan lokal sangat diperlukan agar nilai-nilai luhur dan filosofis yang terkandung di dalamnya dapat dipahami masyarakat luas. Terutama bagi masyarakat luar komunitas yang belum memahami kebudayaan komunitas yang dimaksud. Dalam perspektif teori tindakan sosial Max Weber, fenomena ini digolongkan kedalam tindakan rasional instrumental (zweckrationalitat) karena tindakan ini terarah pada tujuan yakni perilaku yang dilakukan seseorang dengan memperhitungkan kesesuaian antara cara yang digunakan dengan tujuan yang akan dicapai (Taufiq, 2013:177).

Beranjak dari hal tersebut, Kelompok Kayoman Pedawa dapat dikatakan telah melakukan semacam aksi sosial yang terencana dan terarah dalam kaitannya dengan sosialisasi dan publikasi kearifan lokal Desa Pedawa. Dalam kegiatan ini. Selain bekerjasama dengan para perangkat desa secara internal, juga bekerjasama dengan pihak-pihak lain untuk merealisasikan tujuannya memperkenalkan kebudayaan khas Desa Pedawa. Adapun cara yang dilakukan sekaligus pihak yang diajak bekerjasama mensosialisasikan dan mempublikasikan kebudayaan lokal Desa Pedawa adalah sebagai berikut.

1. Melalui Dialog Interaktif Siaran Radio Guntur Singaraja

Dialog interaktif melalui siaran radio merupakan salah satu media sosialisasi yang sering dipergunakan dalam menyiarkan potret kebudayaan yang berbasis kehidupan desa. Siaran radio sudah cukup dikenal luas dan familiar dalam menjangkau pelosok-pelosok pedesaan. Dialog interaktif melalui siaran radio dipilih karena merupakan media sosialisasi yang terjangkau dan murah, bahkan tanpa biaya. Berkaitan dengan hal tersebut, maka siaran radio dianggap cocok untuk mensosialisasikan beberapa aspek kearifan lokal Desa Pedawa. Terselenggaranya dialog interaktif berkat adanya inisiatif dari Kelompok Kayoman Pedawa dengan melakukan request (permohonan) kepada pihak manajemen radio. Salah satu radio yang merespos permohonan tersebut adalah Radio Guntur yang berpusat di Kota Singaraja.

Tanggal 24 Mei 2019 merupakan kali pertama diselenggarakannya dialog interaktif tersebut. Pihak radio mengundang dua perwakilan dari Kelompok Kayoman Pedawa. Dua orang yang mewakili kelompok tersebut yaitu Ketua Kelompok Kayoman Pedawa langsung beserta wakilnya. Dialog interaktif tersebut umumnya membahas tentang kehidupan sosial budaya masyarakat Desa Pedawa yang mencakup religi, mata pencaharian, dan kearifan-kearifan lokal khas Pedawa lainnya. Hanya saja kelemahan dari media sosialisasi siaran radio adalah dialog interaktif tidak diselenggarakan secara rutin untuk satu komunitas masyarakat, melainkan berganti-gantian dengan komunitas lainnya. Hingga saat ini sepanjang tahun 2019, dialog interaktif yang mengulas tentang Desa Pedawa baru berlangsung sebanyak dua kali. Kelemahan lainnya adalah jangkauan sinyalnya yang hanya terbatas pada seputaran wilayah Buleleng. Oleh sebab itu, masyarakat luar Kabupaten Buleleng belum begitu mengenal kearifan lokal Desa Pedawa karena jangkauan yang terbatas.

Hal lainnya yang juga turut menjadi kelemahan cara ini adalah minat generasi muda yang sudah jarang berminat mendengarkan siaran radio. Hal ini diakui pula oleh Ketua Kelompok Kayoman Pedawa, dimana kecenderungan generasi muda sekarang lebih menyukai tontonan berbasis audio-visual. Oleh sebab 
itu, perlu ada upaya-upaya lain yang ditempuh agar berbagai aspek kearifan lokal Desa Pedawa dapat tersosialisasikan dengan baik, sehingga dapat pula menarik minat wisatawan yang lebih banyak untuk mengunjungi Desa Pedawa.

2. Melalui Pembuatan Film Dokumenter yang Bekerjasama Dengan Minikino Bali

Pada bulan Juni 2019, sebuah institusi perfilman dokumenter yang berpusat di Denpasar, yakni Minikino Bali secara kebetulan melakukan survey yang menyasar Desa Pedawa untuk mendokumentasikan budaya dan seni setempat. Pihak desa lalu menunjuk para pemuda yang tergabung dalam Kelompok Kayoman Pedawa untuk menjalin kerjasama untuk mendampingi dan turut terlibat dalam kegiatan tersebut. Maka atas kerjasama yang dijalin antara pihak Minikino Bali dengan Kelompok Kayoman Pedawa, maka sebagai langkah awal diadakanlah kegiatan workshop pembuatan film yang menyasar para pemuda Desa Pedawa. Tujuannya adalah untuk mempublikasikan dan dipromosikan ke khalayak luas. Melalui kegiatan tersebut, diharapkan dapat membangkitkan kecintaan dan kebanggaan para generasi muda dalam mempromosikan kearifan lokal setempat.

Langkah awal dalam mendokumentasikan kearifan lokal Pedawa adalah menyelenggarakan workshop perfilman. Minikino Bali dan Kelompok Kayoman Pedawa lalu berkolaborasi dalam mensosialisasikan pembuatan film-film pendek yang berbasis dokumenter kearifan lokal. Pelaksanaan workshop ini dilaksanakan selama dua hari pada tanggal 1 dan 2 Juni 2019, bertempat di Rumah Adat Bandung Rangki Desa Pedawa. Dalam workshop tersebut, diadakan pula sesi pemutaran film pendek pada malam harinya dengan disaksikan oleh tokoh-tokoh masyarakat, para pemuda, anak-anak, serta masyarakat umum yang berkeinginan menyaksikannya. Kegiatan tersebut dapat dilihat pada gambar berikut.

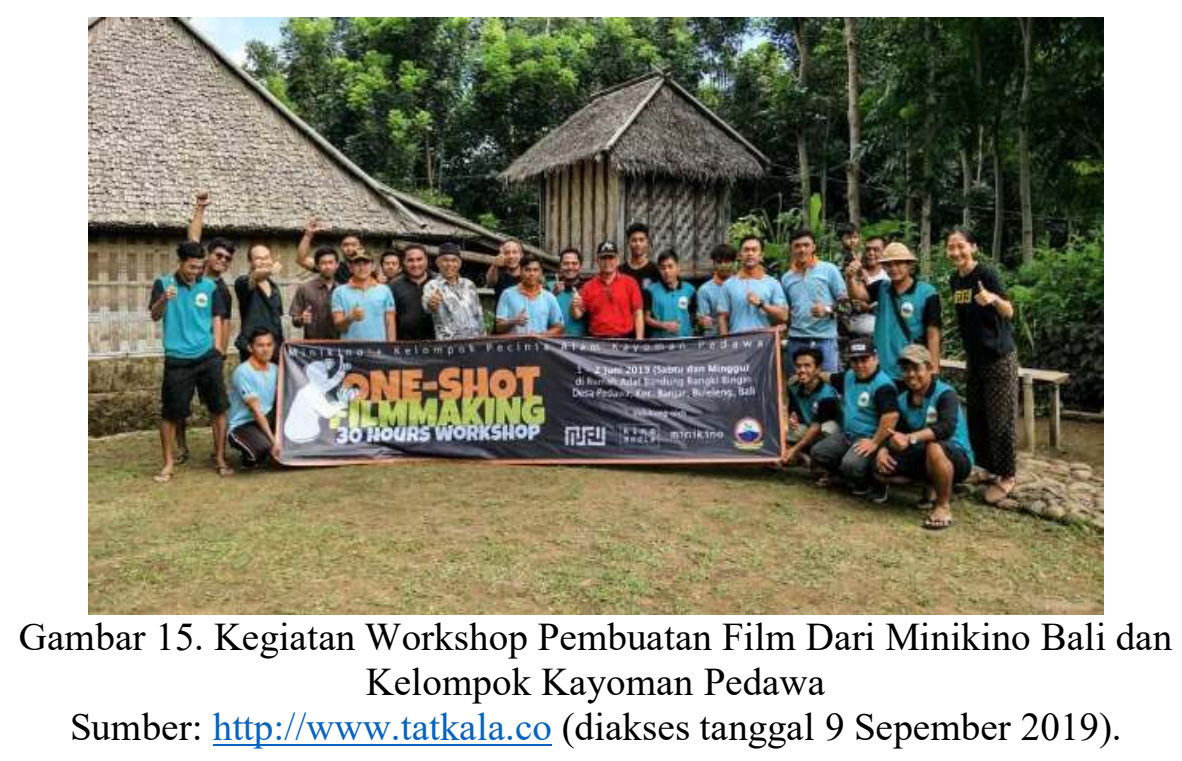




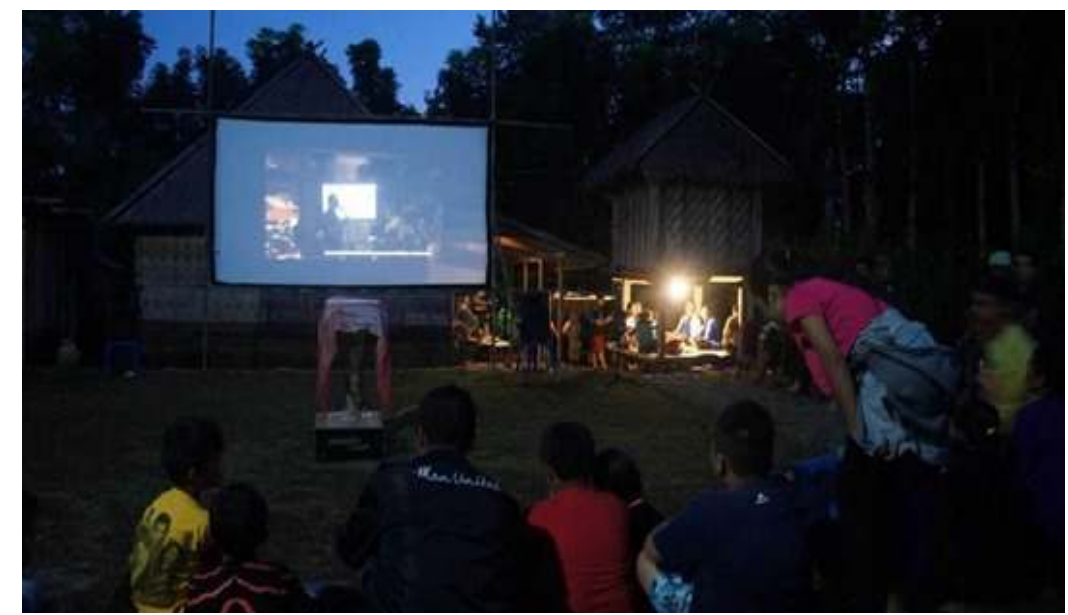

Gambar 16. Sesi Pemutaran Film Pendek Serangkaian Workshop Pembuatan Film Dokumenter Berbasis Kearifan Lokal

Sumber: http://www.tatkala.co (diakses tanggal 9 September 2019).

Tahap berikutnya serangkaian program dari Minikino Bali adalah syuting film yang berlatar kearifan lokal Desa Pedawa. Dalam film tersebut, masyarakat asli Desa Pedawa dilibatkan dalam pembuatannya. Kegiatan-kegiatan tersebut sangat diapresiasi oleh masyarakat setempat, terlebih hasilnya akan dipromosikan sebagai daya tarik wisata berbasis kearifan lokal. Dalam hal ini, Kelompok Kayoman Pedawa memiliki peranan yang sangat besar dalam menuntun dan memberikan pendampingan, serta ikut pula terlibat dalam setiap prosesnya. Dengan demikian, kearifan lokal yang terdokumentasikan dan dipromosikan sesuai dengan kenyataan yang sesungguhnya dan semakin menumbuhkan rasa cinta masyarakat setempat akan kearifan lokalnya.

\section{KESIMPULAN}

Berdasarkan pembahasan di atas, dapat disimpulkan bahwa upaya revitalisasi potensi budaya berbasis kearifan lokal yang dilakukan kelompok Kayoman Pedawa beberapa diantaranya adalah; 1) rehabilitasi hutan dan budaya agrikultur, 2) revitalisasi peninggalan purbakala menjadi destinasi wisata sejarah desa, 3) rekonstruksi atraksi berbasis kearifan lokal, seperti rumah adat, permainan gangsing, rekonstruksi gamelan tradisional khas pedawa, revitalisasi pembuatan dan produk gula aren pedawa, 4) memberikan pendampingan mahasiswa asing yang studi etnografi, dan 5) sosialisasi dan publikasi kearifan lokal Desa Pedawa kepada masyarakat luar, seperti dialog interaktif siaran Radio Guntur Singaraja, melalui pembuatan film dokumenter yang bekerjasama dengan Minikino Bali.

Terkait dengan keseluruhan isi penelitian ini, sebagai penutup dapat diberikan masukan atau saran-saran sebagai berikut. Pertama, kepada pihak pemerintah, khususnya stakeholder di bidang Pariwisata agar memberikan perhatian lebih pada potensi-potensi wisata yang berbasis kearifan lokal, khususnya di Desa Pedawa, karena sejauh ini kelompok Kayoman Pedawa bergerak secara swadaya, dan tentunya memiliki cakupan sumber daya yang terbatas, baik moral maupun finansial. Kedua, kepada para generasi muda hendaknya mampu lebih aktif dalam menggali, mengeksplorasi, serta 
mempromosikan dengan bangga kearifan lokal yang dimiliki sebagai potensi wisata.

\section{DAFTAR PUSTAKA}

Antara, I Ketut. 2007. "Revitalisasi Pasidikaran pada Masyarakat Hindu di Kabupaten Badung (Kajian Bentuk, Fungsi, dan Makna)". Tesis Program Pascasarjana IHDN Denpasar.

Emzir. 2010. Metodologi Penelitian Kualitatif Analisis Data. Jakarta: Raja Grafindo Persada.

Firmansyah, Rahim. 2012. Pedoman Kelompok Sadar Wisata. Jakarta: Direktur Jenderal Pengembangan Destinasi Pariwisata Kementerian Pariwisata dan Ekonomi Kreatif.

Haribawa, Putu Agus dkk. "Analisis Orientasi Stakeholder Untuk Pembangunan Ekowisata di Wilayah Bali Aga, Buleleng, Bali”, dalam Jurnal Media Konservasi, Vol. 22, No. 3.

http://www.tatkala.co/2019/03/20/aku-nau-gati-di-pedawa-kata-mitsuha-abeperempuan-dari-jepang-itu/(diakses 21 Agustus 2019).

Liliweri, Alo. 2009. Dasar-dasar Komunikasi Antarbudaya. Yogyakarta: Pustaka Pelajar.

Mataram, A.A.G. Mayun. 2007. "Revitalisasi Hak Asasi Manusia Umat Hindu di Bali (Perspektif Hukum Hindu)". Tesis Program Pascasarjana IHDN Denpasar.

Nasikun. 2004. Sistem Sosial Indonesia. Jakarta: Raja Grafindo Persada.

Purbasari, Novia dan Asnawi. 2014. "Keberhasilan Community Based Tourism di Desa Wisata Kembangarum, Pentingsari dan Nglanggeran”, dalam Jurnal Teknik PWK, Vol. 3 No. 3.

Purwanto, Sigit dkk. 2014. "Kajian Potensi dan Daya Dukung Taman Wisata Alam Bukit Kelam Untuk Strategi Pengembangan Ekowisata", dalam Jurnal Pengelolaan Sumberdaya Alam dan Lingkungan, Vol. 4, No. 2.

Riana. 2014. "Perbedaan Persepsi Nasionalisme Antara Masyarakat Jawa dengan Keturunan Tionghoa (Studi di Kampung Balong Kelurahan Sudiroprajan Kecamatan Jebres Surakarta Tahun 2013)". Skripsi Fakultas Keguruan dan Ilmu Pendidikan Universitas Sebelas Maret Surakarta

Ritzer, George. 1985. Sosiologi Ilmu Pengetahuan Berparadigma Ganda. Jakarta: Rajawali.

Ritzer, George dan Douglas J. Goodman. 2007. Teori Sosiologi Modern. Jakarta: Kencana.

Setyosari, H. Punaji. 2010. Metode Penelitian Pendidikan. Jakarta: Kencana.

Susyanti, Dewi Winarni dan Nining Latianingsih. 2014. "Potensi Desa Melalui Pariwisata Pedesaan", dalam Jurnal Epigram, Vol. 11, No. 1.

Taufiq, A. 2013. "Perilaku Ritual Warok Ponorogo Dalam Perspektif Teori Tindakan Max Weber”. Jurnal Sosiologi Islam, 3 (2).

Website Resmi Pemerintah Kabupaten Buleleng. 2017. Permainan Gangsing. https://bulelengkab.go.id/detail/artikel/permainan-gangsing-33 (diakses 29 Juli 2019). 
Widiastini, Ni Made Ary dkk. 2018. "Pengembangan Pariwisata Pedesaan di Kabupaten Buleleng”, dalam Prosiding Seminar Nasional Riset Inovatif, 2018, hal: 372-383.

Wijana, Nyoman. 2013. "Pengelolaan Hutan Berbasis Kearifan Lokal di Desa Tigawasa, Kecamatan Banjar, Kabupaten Buleleng", dalam Prosiding Seminar Nasional MIPA, 2013.

Wirawan, I.B. 2012. Teori-Teori Sosial Dalam Tiga Paradigma. Jakarta: Kencana. Zoetmulder, P.J. 2006. Kamus Jawa Kuna-Indonesia. Jakarta: Gramedia Pustaka Utama. 